\title{
A Homogeneous Method for the Conveniently Scalable Palladium- and Nickel-Catalyzed Cyanation of Aryl Halides
}

Finn Burg, Julian Egger, Johannes Deutsch and Nicolas Guimond* Chemical Development, Bayer Pharma AG, Friedrich-Ebert-Straße 217333, 42096 Wuppertal, Germany nicolas.guimond@bayer.com Supporting Information

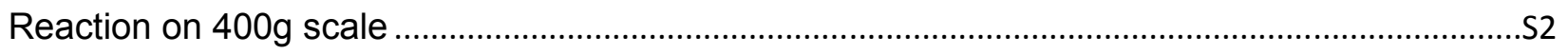

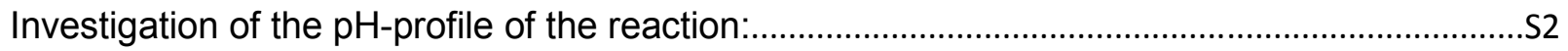

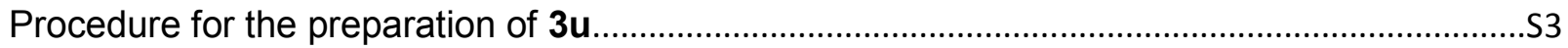

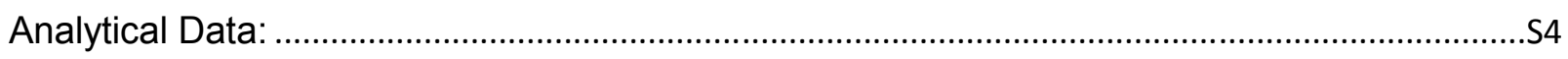

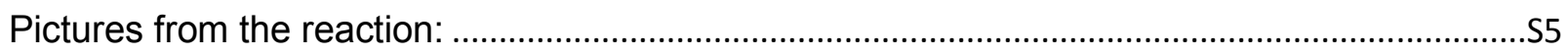

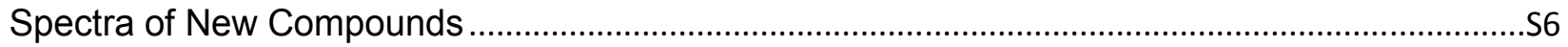




\section{Reaction on $400 \mathrm{~g}$ scale}<smiles>COc1ccc(Br)c(C)c1[N+](=O)[O-]</smiles>

$1 \mathrm{u}$

[400 g]
1. $[\mathrm{Pd}(\text { cinnamyl }) \mathrm{Cl}]_{2}(1 \mathrm{~mol} \%)$ XPhos (3 mol\%) acetone cyanohydrin (1.2 eq) $\mathrm{Et}_{3} \mathrm{~N}$ (2 eq.) i-PrOH (10-fold), $80^{\circ} \mathrm{C}$

2. Cool down, $\mathrm{H}_{2} \mathrm{O}$, filtration $(97 \%)$<smiles>COc1ccc(C#N)c(C)c1[N+](=O)[O-]</smiles>

$3 \mathrm{u}$

[303 g]

Investigation of the $\mathrm{pH}$-profile of the reaction:

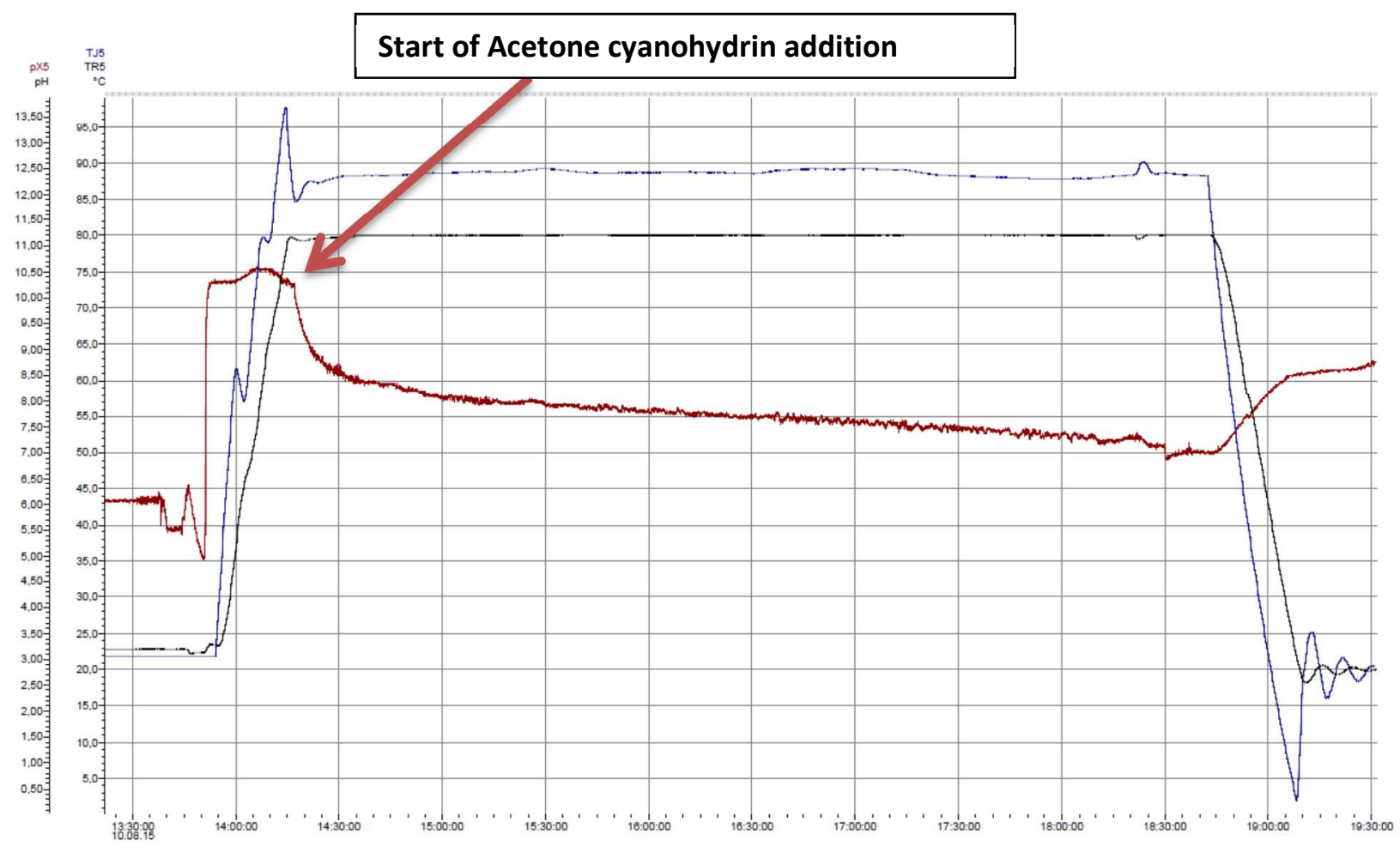

Figure S1: Monitoring of the $\mathrm{pH}$-Value (red), the jacket temperature (blue) and the internal temperature (black) during the course of the reaction. Immediately after the start of addition of the acetone cyanohydrin (14h15) the $\mathrm{pH}$ dropped very sharply from 10.3 to approx. 8.5. 


\section{Procedure for the preparation of $\mathbf{3 u}$}

2-Nitro-3-methyl-4-cyanoanisole (3u). A $6 \mathrm{~L}$ double-walled glass reactor was charged with aryl bromide $\left(400 \mathrm{~g}, 1.63 \mathrm{~mol} .1\right.$ eq.), $\left[\mathrm{Pd}\left(\right.\right.$ cinnamyl) $\mathrm{Cl}_{2}$ (8.42 g, $16.25 \mathrm{mmol}, 1.0 \mathrm{~mol} \%)$ and XPhos (23.2 g, $48.8 \mathrm{mmol}, 3.0 \mathrm{~mol} \%)$ and flushed with $\mathrm{N}_{2}$ for $30 \mathrm{~min}$. In the meantime a mixture of $i-\mathrm{PrOH}$ (1610 $\mathrm{mL}$ ) and $\mathrm{Et}_{3} \mathrm{~N}$ (453 mL, $3.25 \mathrm{~mol}, 2$ eq.) was degassed for 30 min with a stream of $\mathrm{N}_{2}$ and then added to the reaction vessel. The resulting yellow suspension was heated within $30 \mathrm{~min}$ to $80^{\circ} \mathrm{C}$ and became a clear solution. To the reaction mixture was added a solution of acetone cyanohydrin (179 $\mathrm{mL}, 1.95 \mathrm{~mol}, 1.2 \mathrm{eq})$ in degassed $i-\mathrm{PrOH}(1610 \mathrm{~mL})$ slowly with a pump. The first $1 / 3$ was added at a rate $3.3 \mathrm{~g} / \mathrm{min}$ and the remaining $2 / 3$ were added at a rate of $6.1 \mathrm{~g} / \mathrm{min}$. The total addition time resulted in $5 \mathrm{~h} 24 \mathrm{~min}$. Upon completion of the addition the reaction was checked for full conversion and then cooled to $0{ }^{\circ} \mathrm{C}$ over $1 \mathrm{~h}$. At $58{ }^{\circ} \mathrm{C}$ the desired product precipitated. At $0{ }^{\circ} \mathrm{C} 1 \mathrm{~L}$ of water was added and the mixture stirred for another $1 \mathrm{~h}$. Then the product was filtered and the filter cake was washed with water $(3 \times 500 \mathrm{~mL})$. An easy to filter white powder of excellent purity was obtained and dried in a vacuum oven for $48 \mathrm{~h}$ at $40{ }^{\circ} \mathrm{C}$. $303 \mathrm{~g}(97 \%$ yield) of $3 u$ were obtained. The amount of residual $\mathrm{Pd}$ was determined via XRFS and a value $29 \mathrm{ppm}$ was obtained.

${ }^{1} \mathrm{H}$ NMR (400 MHz, $\left.\mathrm{CDCl}_{3}, 293 \mathrm{~K}, \mathrm{TMS}\right): \delta=7.70$ (d, $\left.J=8.8 \mathrm{~Hz}, 1 \mathrm{H}\right), 6.99$ (d, $J=8.8 \mathrm{~Hz}, 1 \mathrm{H}), 3.97$ (s, 3H), 2.49 (s, 3H).

Spectral data match the one previously reported. ${ }^{1}$

${ }^{1}$ Cannon, J. G.; Lukszo, J.; Max, G. A. J. Heterocyclic Chem. 1983, 20, 149-153. 


\section{Analytical Data:}

\section{HPLC trace of isolated product:}

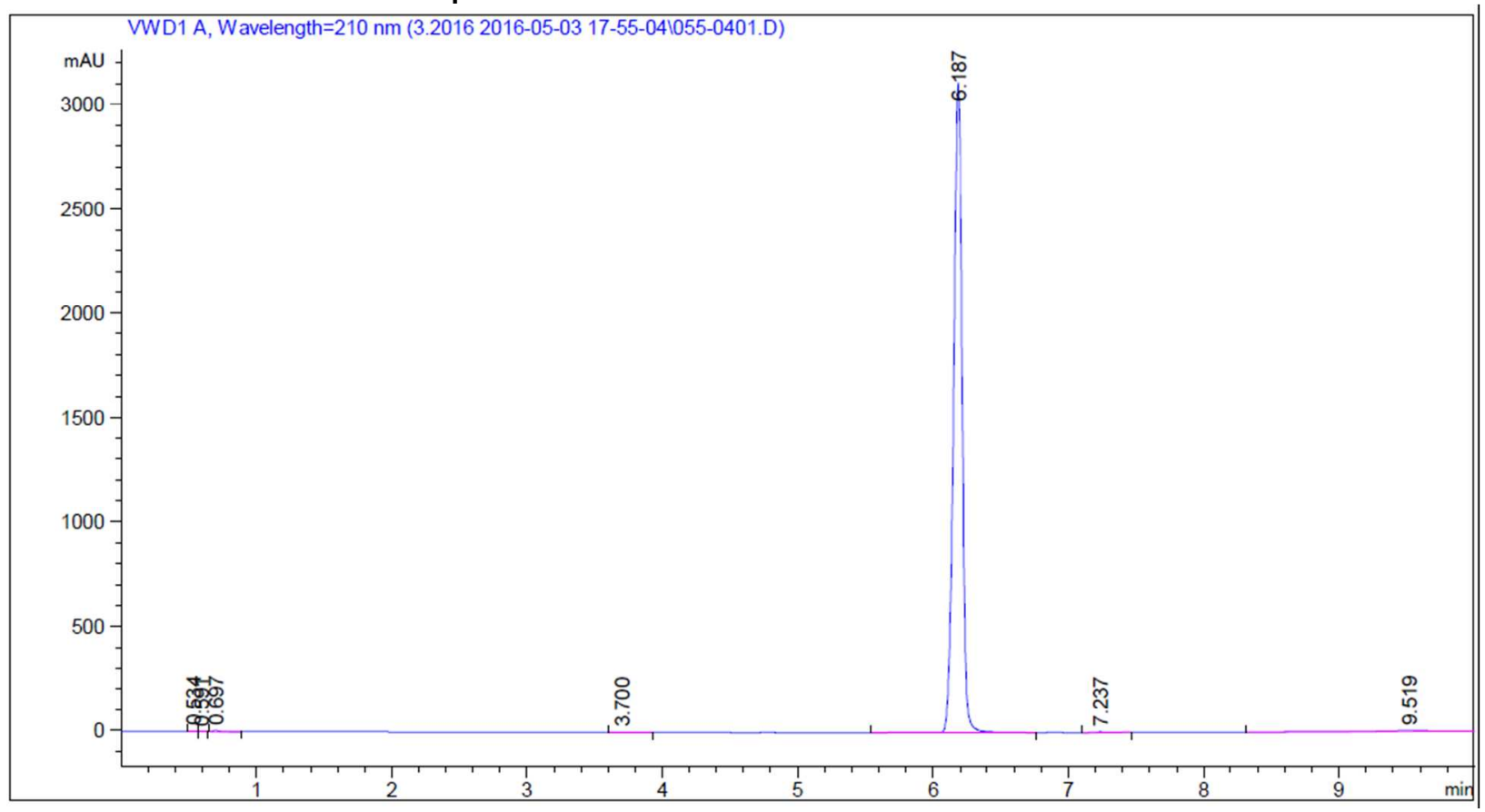

\begin{tabular}{|c|c|c|c|c|c|c|}
\hline $\begin{array}{c}\text { eak } \\
\#\end{array}$ & $\begin{array}{c}\text { RetTime } \\
\text { [min] }\end{array}$ & Type & $\begin{array}{l}\text { Width } \\
\text { [min] }\end{array}$ & $\begin{array}{c}\text { Area } \\
{\left[\mathrm{mAU}{ }^{*} \mathrm{~s}\right]}\end{array}$ & $\begin{array}{l}\text { Height } \\
\text { [mAU] }\end{array}$ & $\begin{array}{c}\text { Area } \\
\%\end{array}$ \\
\hline & & & & & & \\
\hline 1 & 0.534 & VV & 0.0459 & 7.80850 & 2.53735 & 0.0565 \\
\hline 2 & 0.591 & VB & 0.0581 & 8.53487 & .36567 & 0.0617 \\
\hline 3 & 0.697 & BV & 0.0778 & 38.36250 & 7.01471 & 0.2775 \\
\hline 4 & 3.700 & VB & 0.0622 & 8.27051 & 2.00100 & 598 \\
\hline 5 & 6.187 & VV R & 0.0669 & $1.35875 e 4$ & 3115.90723 & 913 \\
\hline 6 & 7.237 & BV R & 0.0679 & 13.58410 & 2.99739 & 0983 \\
\hline 7 & 9.519 & $\mathrm{BBA}$ & 99 & 159.64030 & .62259 & 1.1548 \\
\hline
\end{tabular}

XRFS values (remaining Pd):

\begin{tabular}{|c|c|c|c|c|c|c|c|}
\hline Compound & Si & $\mathbf{P}$ & $\mathbf{C l}$ & $\mathbf{F e}$ & $\mathbf{B r}$ & $\mathbf{P d}$ & C9H8N203 \\
\hline Conc & 31,0 & 2933,3 & 0,0 & 3,5 & 557,6 & 29,3 & 99,645 \\
Unit & $\mathrm{ppm}$ & $\mathrm{ppm}$ & $\mathrm{ppm}$ & $\mathrm{ppm}$ & $\mathrm{ppm}$ & $\mathrm{ppm}$ & $\%$ \\
\hline
\end{tabular}


Pictures from the reaction:

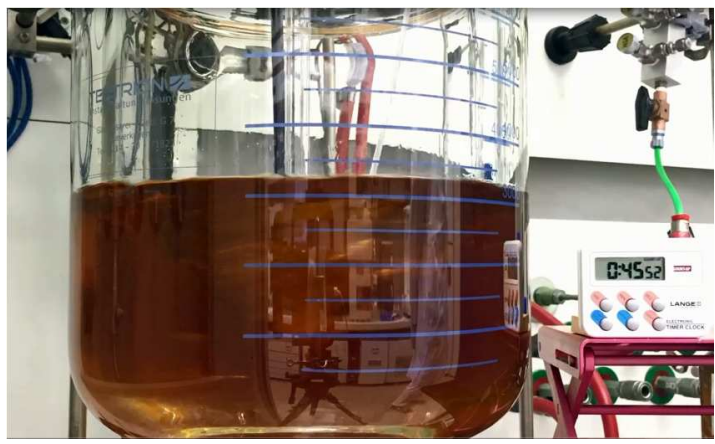

Beginning of dosing

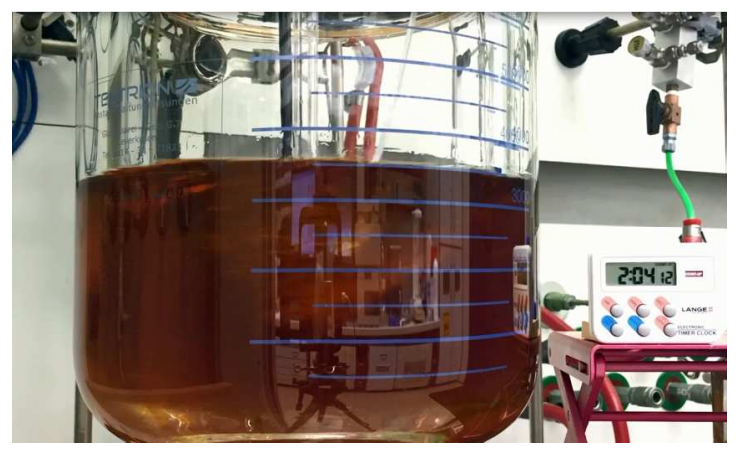

$\sim 1 \mathrm{~h} 15$

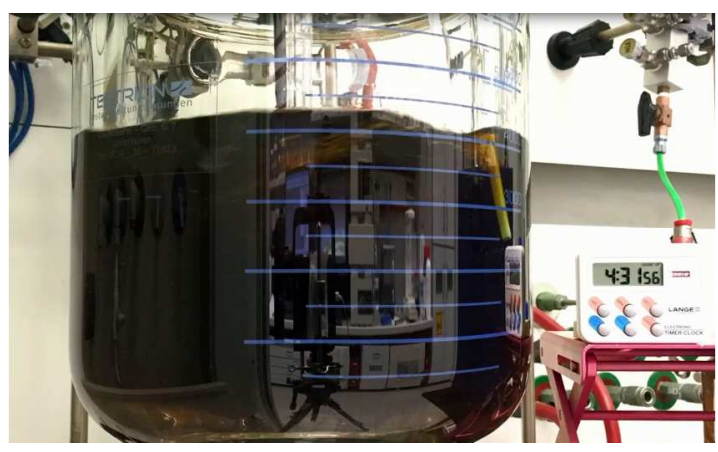

$\sim 3 \mathrm{~h} 45$
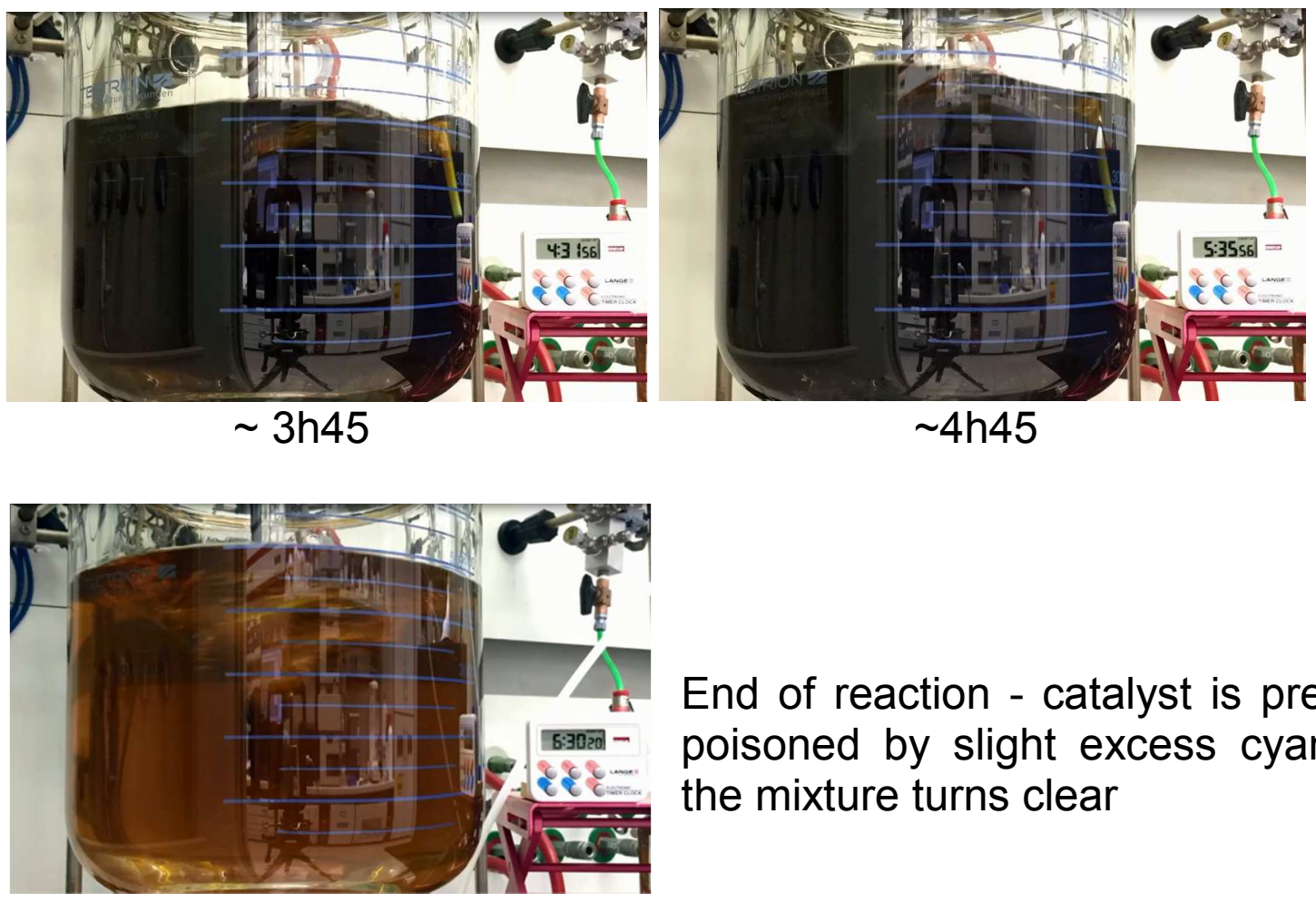

End of reaction - catalyst is presumably poisoned by slight excess cyanide and the mixture turns clear

From left to right: 1) reaction mixture being filtered after crystallization, 2) filter cake and 3) dried product
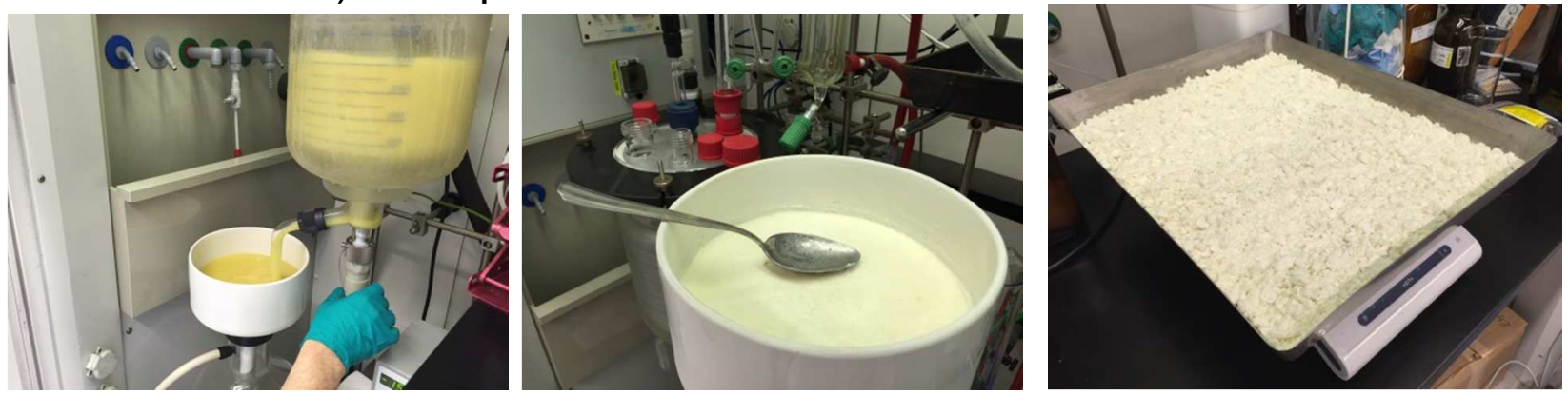


\section{Spectra of New Compounds}

\section{Compound $3 \mathrm{a}{ }^{1} \mathrm{H}$ NMR (500 MHz, DMSO- $\left.d_{6}\right)$ :}

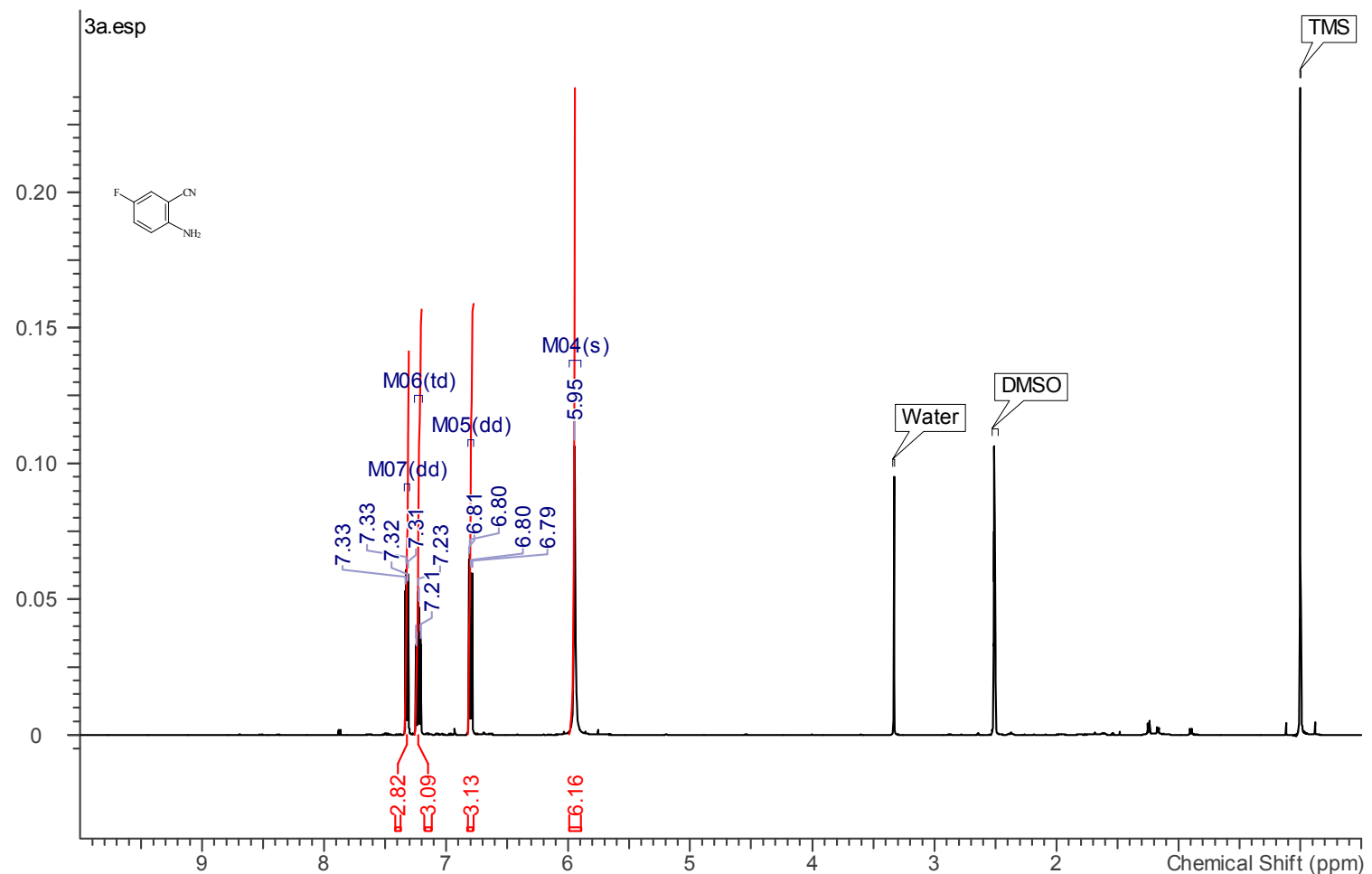

Compound $3 a{ }^{13} \mathrm{C}$ NMR (125 MHz, DMSO- $\left.d_{6}\right)$ :

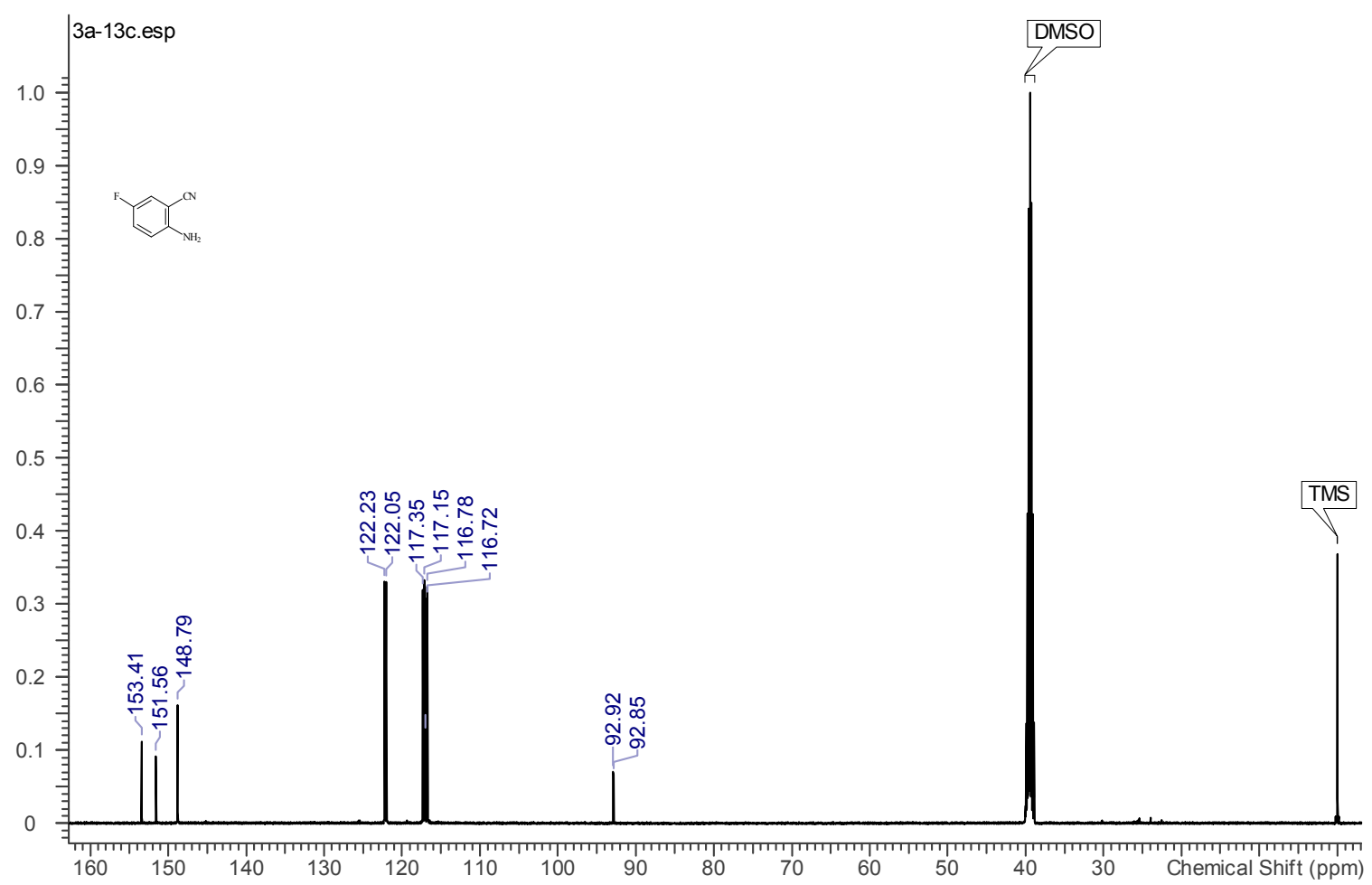


Compound $3 \mathrm{~h}{ }^{1} \mathrm{H}$ NMR (500 MHz, DMSO- $d_{6}$ ):

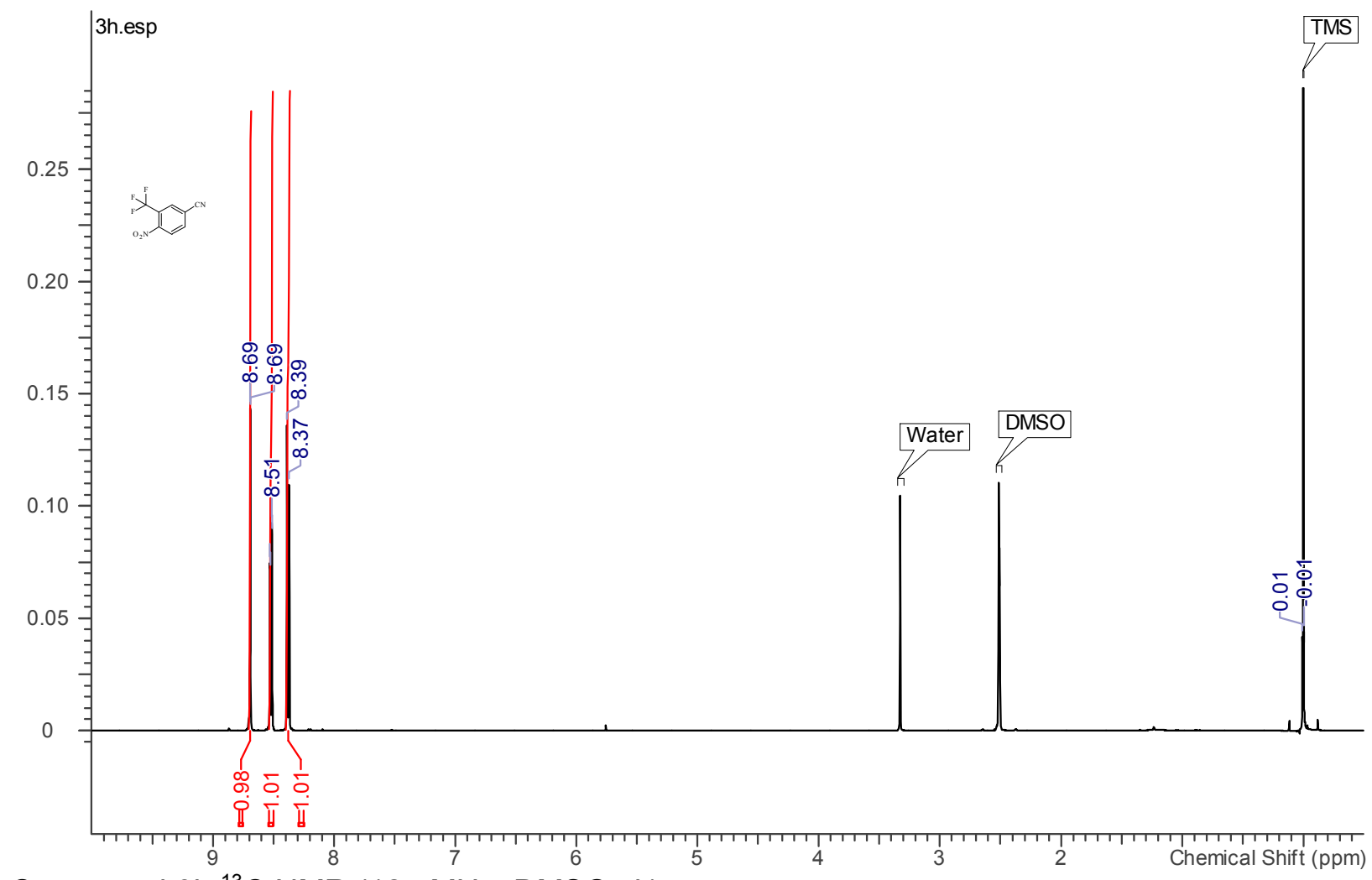

Compound $3 \mathrm{~h}{ }^{13} \mathrm{C}$ NMR (125 MHz, DMSO- $\left.d_{6}\right)$ :

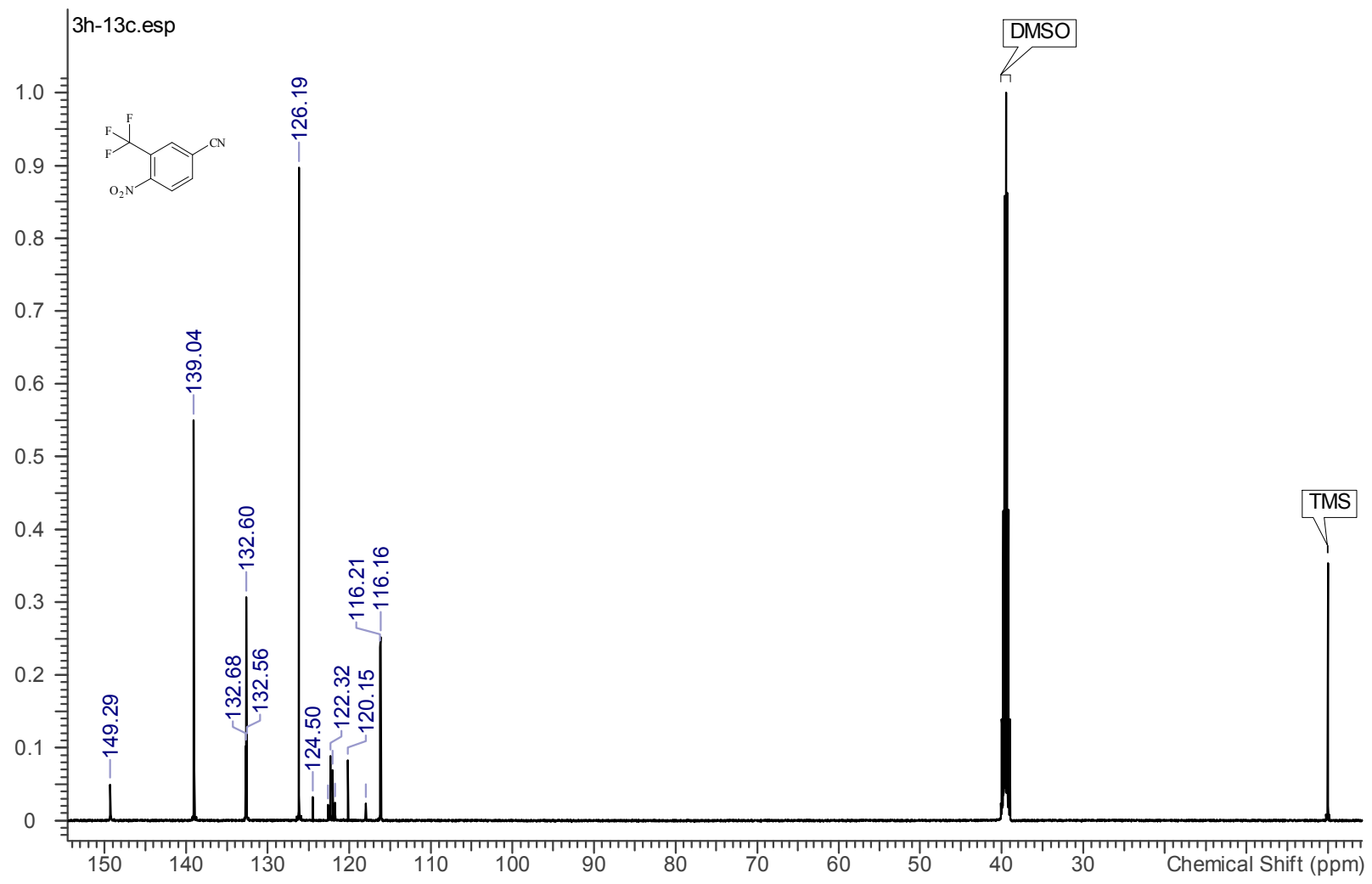


Compound $3 r^{1} \mathrm{H}$ NMR (500 MHz, DMSO- $\left.d_{6}\right)$ :
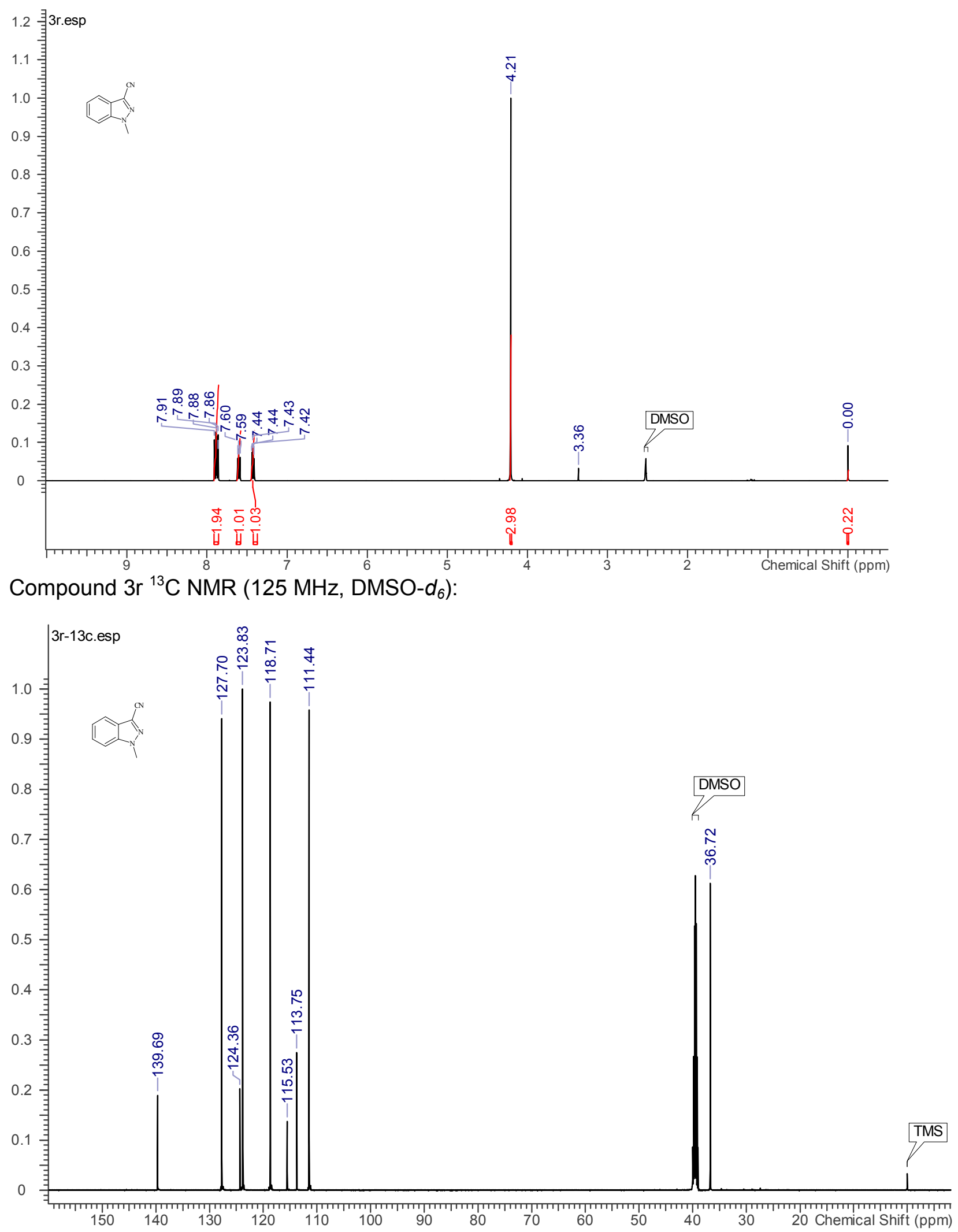